\title{
THE FACEBOOK PHENOMENON FOR COLLABORATIVE LEARNING FOR UNIVERSITY STUDIES
}

\section{VOLUNGEVIČIENĖ Airina, TERESEVIČIENĖ Margarita, MEJERYTÉ- NARKEVIČIENĖ Kristina}

Vytautas Magnus University, Kaunas, Lithuania

\begin{abstract}
This article defines the shift in the concept and conditions of collaborative learning for university studies using the social networking tool Facebook and discusses the collaborative learning effect in terms of using Open Educational Resources (OER), creating learning artefacts and new generic competence development. In order to evaluate students' learning through collaboration in Facebook, qualitative research method and survey of generic competencies based on the Tuning project framework (2003) were used. The data was collected through focus group interviews and analyzed using qualitative content analysis. The qualitative research method was chosen because it provides information of how students collaborate and what experience they gained during the activities. First, Facebook online groups have been identified at three different levels at VMU. The Facebook first level group was the social networking of Vytautas Magnus University's students and academic staff. The second level group was created for the department dealing with social sciences, and is called "Department of Social Science". The third level group is "Education Service Management" within the Department of Education. The research was done at the third level group with the students of the "Education Service Management" study programme. As research results show, Facebook as a social network has been changing communication between students, by facilitating the exchange of information and knowledge. The research analyses Facebook in the context of undergraduate university studies, based upon the experience of Vytautas Magnus University (VMU) for using Facebook for university studies. It could be concluded that learning is about developing capabilities to think and to act. Learners using social networking tools for collaborative learning, act, provide feedback and peer-review, asses and rate information. Openness is based on the idea that knowledge is disseminated and shared freely for the benefit of society as a whole. University students collaborate online and learn by using and exchanging OER, as well as developing them as the artefacts of online collaborative learning. They influence task design by creating "educational resources" themselves.
\end{abstract}

Keywords: Collaborative learning; Facebook; University; Students; Studies. 


\section{Background}

Higher education institutions are dealing with the challenge of shifts in the way studying is organized due to the modernization of the study process, as well as changes in learning methods, processes and tools. Collaborative learning has been considerably expanded from the formal environment of university study into the broad international peer-supported learning environment, facilitated by the advent of Web 2.0 tools. According to Redecker et al. (2009), the new learning methods open up society, embrace diversity, implement networking, increase academic achievement and improve learning. The new methods of learning promote technical, pedagogical and organization innovation. This article analyses these innovations from the point of view of collaborative learning in university studies that uses Facebook, which facilitates the use and exchange of information and knowledge, and promotes the development of educational artefacts, i.e. open educational resources.

This article covers several aspects. First, the concept of collaborative learning is defined, as well as its development with the advent of Web 2.0 resources which changes the organization of the study process within a university. This chapter discusses how the concept of collaborative learning changes concerning university studies. Second, the purpose of student collaboration using Facebook is highlighted. Facebook is becoming an important part of studies, and a large majority of students share, use and exchange information and educational resources using Facebook. Facebook users have indicated that they are able to successfully collaborate in this informal context, learning and sharing information for study and other purposes. Facebook has been changing the way students communicate among themselves and with other people, how they exchange information, and also how they produce knowledge. VMU has established their own Facebook group, as have different departments and student groups and online communities. They create content together, which allow for informal learning activities and collaboration experiences for fulfilling university study tasks. Facebook is used on different levels within university studies (on the departmental level, the faculty level, and on the level of the wider university community). However, it is difficult to understand how collaborative learning occurs. In addition it is also difficult to ascertain the precise characteristics of collaborative learning experience among Facebook members at VMU, and how this informal collaborative experience contributes to successful university studies.

The research aim was to define the Facebook phenomenon for collaborative learning at university studies. This article discusses the experience of the Facebook student group of the Department of Education at the Faculty of Social Sciences at VMU. The empirical research also focuses on the relationship between communities, networks, groups and individual learning, as well as on collaborative online learning for formal and informal education. 
DOI: 10.1515/arhss-2015-0006 Applied Research in Health and Social Sciences: Interface and Interaction, Vol. 12, No. 1, 2015

\section{Methodology}

\section{Sample}

VMU students who were registered in Facebook were chosen for the research according to voluntary principle. All students who participated in the research were members of the "Education Service Management" study programme group in Facebook. 21 fourth-year students of the "Education Service Management" (VMU) study programme were interviewed by two VMU researchers during the period of research. The respondents' age of the two focus groups ranged from 21 to 23 years old, and $90.5 \%$ of them were females while only $9.5 \%$ were males.

\section{Methods}

Two focus groups were interviewed with the aim of identifying the concept of collaborative learning for university studies, identifying their knowledge and skills on the use of Facebook, their experience and need to participate in the networking groups, to clarify the use of Facebook for university studies, to find characteristics of the learning process at Facebook online communities, and to define additional general competencies users gain when employing Facebook

In order to evaluate students' learning through collaboration in Facebook, qualitative research method and survey of generic competencies based on the Tuning project framework (2003) were used. The data was collected through focus group interviews and analyzed using qualitative content analysis.

The qualitative research method was chosen because it provides information of how students collaborate and what experience they gained during the activities. First, Facebook online groups have been identified at three different levels at VMU. The Facebook first level group was the social networking of Vytautas Magnus University's students and academic staff. The second level group was created for the department dealing with social sciences, and is called "Department of Social Science". The third level group is "Education Service Management" within the Department of Education. The research was done at the third level group with the students of the "Education Service Management" study programme.

\section{Tool}

First, the instrument for the interview was a structured questionnaire prepared for the research, and was made following 3 criteria: 1) collaborative learning in university studies; 2) students' collaboration in Facebook and factors in participation; 3) collaboration in Facebook through OER. The structured interview was performed in order to reveal the factors concerning student collaboration in Facebook. 
DOI: 10.1515/arhss-2015-0006 Applied Research in Health and Social Sciences: Interface and Interaction, Vol. 12, No. 1,2015

Second, the list of the generic competencies by the Tuning project framework was adapted for the students in order to see what kind of competencies they develop during collaboration. All generic competencies had to be marked from 1 to 5 points using the Likert scale (1- strongly disagree, 2 disagree, 3 - neither agree nor disagree, 4 - agree, 5 - strongly agree). Third, research participants were divided in two separated Focus groups and were interviewed by two researchers from Vytautas Magnus University using the structured interview questionnaire. All interviews were recorded. At the end of the interview, respondents were asked to mark the competencies in the competencies list provided using the Likert scale. Fourth, the data from the interviews were transcribed and analyzed by Qualitative content analysis.

\section{Ethics}

Research was based on principles of diagnostic ethics: benevolence, respect of personality, justice and right to receive precise information.

\section{The concept and purpose of collaborative learning in university studies}

Learning is a process of transforming experience into knowledge, skills, and attitudes through a variety of processes (Galbraith, 1995). There are three types of learning: formal learning, non-formal learning, and informal learning. Formal learning refers to systematic processes and pre-planned activities that generally are provided by educational institutions and organizations to obtain certain desired goals. Nonformal learning occurs outside the educational system; however, learning activities can be organized as well for target learners to achieve certain learning objectives. Informal learning refers to the individual gains of skills, knowledge, and attitudes from everyday experience and from one's social environment. In all those three types of learning, the learners are more motivated to learn (and retain knowledge) more effectively and develop more skills for life if they work together. It means that collaborative learning is applied in all these learning types.

Collaborative learning is an educational approach to teaching and learning that involves groups of learners working together to solve a problem, complete a task, or create a product. Collaborative learning is based on the idea that learning is a naturally social act in which the participants talk among themselves. It is through this interaction that learning occurs. Collaborative learning itself is hardly a new idea, as it seems likely that people have been learning informally in groups for thousands of years. 
DOI: 10.1515/arhss-2015-0006 Applied Research in Health and Social Sciences: Interface and Interaction, Vol. 12, No. 1,2015

The concept of collaborative learning, along with the grouping and pairing of learners for the purpose of achieving a learning goal has been widely researched and advocated. The term "collaborative learning" refers to an instruction method in which learners at various performance levels work together in small groups toward a common goal. Fullan (1993) described the collaborative learning term as a joint process when two or more learners as individuals with the complementary skills work together to create a common understanding which none of them had previously and would not have been able to achieve by themselves. The learners are responsible for each other's learning, as well as for one's own learning. Thus, the success of one learner helps other students to be successful.

When one thinks of collaborative learning, a number of aspects of learning should be kept in mind: learning is an active process whereby learners assimilate the information and relate this new knowledge to a framework of prior knowledge; learning requires a challenge that opens the door for the learner to actively engage his/her peers, and to process and synthesize information rather than simply memorize and reproduce it; learners benefit when exposed to diverse viewpoints from people with varied backgrounds; learning flourishes in a social environment where conversation between learners takes place; during these intellectual gymnastics, the learner creates a framework and meaning to the discourse; in the collaborative learning environment, the learners are challenged both socially and emotionally as they listen to different perspectives, and are required to articulate and defend their ideas. In so doing, the learners begin to create their own unique conceptual frameworks and not rely solely on an expert's or a text's framework. Thus, in a collaborative learning setting, learners have the opportunity to converse with peers, present and defend ideas, exchange diverse beliefs, question other conceptual frameworks, and be actively engaged (OECD, 2007).

Asynchronous online collaborative learning communities demonstrate an effective learning process. Ocker and Yaverbaum (1999) found that asynchronous collaboration is as effective as face-to-face (FTF) collaboration in terms of learning, quality of the solution, solution content, and satisfaction with the solution quality. Additionally, Hiltz (1998) has argued that an online learning community with a collaborative design is more effective than working individually. Collaboration can be facilitated by wellconstructed software to support group activities and interaction, however it can only facilitate the desired behaviour, not produce it. Collaborative technologies mediate the interactions between learners with the aim to support their collaborative learning activities. Collaborative technologies may be considered as new tools that provide students a "space for authoring themselves" (Holland et al., 1998, 169 p.). Today, technology is seen as a revolutionary tool to build online communities, strengthen relationships and 
DOI: 10.1515/arhss-2015-0006 Applied Research in Health and Social Sciences: Interface and Interaction, Vol. 12, No. 1, 2015

mobilize joint planning. Technology is used as a tool for learning, and as the research showed the students use more and more social networks for this purpose.

Collaborative learning occurs as a result of interaction between peers engaged in the completion of a common task. Learning can occur either in an immersion environment like a classroom or in a virtual space such as an online discussion forum in Facebook. The social aspect of learning is at the heart of a collaborative approach. With the growing rise of social networking sites and discussion forums, today interaction between peers is easier than ever before. Interaction is getting easier particularly between those people who are geographically dispersed.

According to Johnson, Johnson and Smith (1991) there are three key factors for effective collaborative learning: group composition, task features, and communication media. Group composition is defined by several variables: the age and levels of participants, the size of the group, the difference between group members, etc. The effects of collaboration vary according to the task. Some tasks encourage more active participation and collaboration than others. For instance, some tasks are inherently distributed and lead group members to work on their own, independently from each other. Some tasks may be so straightforward that they do not leave any opportunity for disagreement or misunderstanding. Some tasks do not involve any planning and hence create no need for mutual regulation. Some tasks cannot be shared, because they rely on processes (e.g. perception) which are not open to introspection or skills (e.g. motor skills) that leave no time for interaction. Sometimes the communication medium spurs collaboration. In essence, most of current widely available internet-based tools use text-based communication, synchronous or asynchronous, with mostly fixed graphics and images. Voice and video interaction or voice and video mail are of course available, but the overload of standard networks and the limits of currently available hardware have postponed their larger use in current distance education.

Many researchers (Johnson et al., 1991; Arends, 1998; Bennet et al., 2000) found that collaborative learning is instruction that involves students working in teams to accomplish a common goal with five conditions: positive interdependence, individual accountability, face-to-face promotive interaction, appropriate use of collaborative skills, group processing.

Today the benefits of collaborative learning are widely known but rarely practice, particularly at the university level. Numerous studies (Slavin, 1991; Johnson \& Johnson, 1987; Kagan, 1988) showed that collaboration achieved better results like better performance and productivity, a longer duration of active learning, a higher level of critical thinking, positive approach to education, better motivation, more perceived differences between people, caring for one another, and better self-esteem. Panitz (1997) has listed 67 distinct benefits - which range from academic and social to psychological benefits - that can be 
DOI: 10.1515/arhss-2015-0006 Applied Research in Health and Social Sciences: Interface and Interaction, Vol. 12, No. 1,2015

expected from the use of group work. These include such factors as building self-esteem, reducing anxiety, encouraging understanding of diversity, fostering relationships and stimulating critical thinking. In addition the benefits of collaborative learning include time saving, the option to brainstorm with peers about the best format learning should take, the development of good interpersonal skills including team work and effective communication, the opening up of possible access to resources, and guarantee the use of existing resources.

\section{The shift in collaborative learning using web 2.0 tools}

As indicated in the previous chapter, the conditions for collaborative learning are based on group composition, task features and communication media (Johnson, Smith, 1991). As discussed in the chapter above, the biggest change should occur in community expansion and its composition, as Web 2.0 tools expand the group composition drastically in terms of geographical, cultural and national scope, making it difficult if not impossible to limit it to one specific context. Group composition might depend upon the communication media used, as online communities might be built using different Web 2.0 tools and might belong to different online community sets, but also might be interlinked and mingled through various technological solutions. Thus collaborative learning changes within university formal studies can be defined as having all three innovations mentioned by Redecker et al. (1991): a) technological innovation, b) pedagogical innovation, and c) organization innovation. Technological innovation is supported by the use of Facebook for informal and formal collaborative learning via information and resource exchange. Pedagogical innovation is characterised by changes in task composition, enlarging the scope of the task itself, broadening learning results and peer-produced artefacts, as well as increasing validity of the discussions and collaborative learning outcomes. Organization innovation can be traced by the expansion of international and intercultural settings, peer -institutions, individuals, blended formal and non-formal discussions. The learning process is expanded to learner-controlled and online community controlled processes, when a university teacher undertakes the role of an expert and consultant and defines and maps learning results in the context of the study program and the composition of its learning outcomes.

Dillenbourg et al. (1996) suggest that the question "Under which conditions the collaborative learning is efficient?" is split into two sub-questions: which interactions occur under which conditions and what effects do these interactions have? This research does not aim to evaluate the effects of the interactions of collaborative learning, but to address the first half of the question and to identify the conditions and the interactions that university students have using Facebook for collaborative learning. 
In a traditional setting, the collaborative learning process would be biased by traditional classroom settings, asynchronous communication and a teacher-controlled outcome. The online collaborative learning process using Web 2.0 tools is under no conditions controlled by an individual or even an institution. Social networking and online community inter-cultural settings make the teacher and the individual an observer and contributor to sharing and the peer-reviewing process, leaving the decision to be interpreted by the group that agrees to collaborate on a given task (they share and exchange information, knowledge and feedback in each phase, designing a collaborative learning artefact).

As mentioned in the chapter above, collaborative learning is instruction that involves students working in teams to accomplish a common goal under five conditions, which include positive interdependence, individual accountability, face-to-face promotive interaction, appropriate use of collaborative skills, and group processing. When collaborative learning changes from a traditional to an online environment, changes to some collaborative learning conditions inevitably occur, on top of the changes mentioned above, while others are facilitated by web 2.0 tools.

First, positive interdependence which is mediated by Web 2.0 tools can be analyzed more thoroughly, which allows for the carrying out of research on interaction. The application of Web 2.0 tools for mediated collaborative interaction can be tracked individually, which increases the possibility to identify and highlight individual accountability (in terms of individual contribution). However, not only are contributions in terms of statistics the focus of the research, but also individual interests and the competence level, and even skills, abilities and values can be traced and described from the point of view of individual characteristics, the purpose of the interaction during collaborative learning process, and many more.

Second, particular conditions of collaboration change very drastically, namely "face-to-face promotive interaction" are replaced by new typology of interaction that has been suggested by several authors. Paulsen (2004) suggested a classification of interaction on the basis of participants, when interaction occurs one-to-one, one-to-many, and many-to-many participants. He classified tools on the basis of their functionality that allow for these types of interaction. If interaction is based on the theory of social presence (Biocca et al., 2006) or in other words the impression of "being there", then interaction is based on the classification of social presence as: a) perceived social richness of the medium, b) involvement, immediacy or intimacy, c) social judgements of the other, d) single or two item measures, or e) behavioural measures.

Focusing on Facebook as a social networking Web 2.0 tool that creates possibilities to expand group composition (breaking the formal institutional environment down into numerous, unlimited topic-based 
groups that work on a topic in international and intercultural settings), task features (from a pedagogical point of view task features change, as new feedback and peer-review, new types of interaction occur, increasing the quality and validity of the task itself and its artefact), ensures mediated task implementation with the possibilities to track individual accountability, and positive interdependence for a large number of external group members or sub-groups (if they are naturally formed), and mediated communication and unlimited peer-reviews. Facebook use replaces face-to-face promotive interaction with online open community promotive interaction.

Third, the condition addressing participant collaborative skills and competences changes greatly, introducing new challenges to group members. On the one hand, collaborative learning group members should keep their collaborative skills and competences updated, which is contrast to traditional collaborative learning. On the other hand, the growing unlimited online community, as well as international and intercultural features of this community, challenge participants with new requirements which include skills to master mediated communication, Web 2.0 tools, and implement communication in international and intercultural settings. This is also related with the last condition, which is group processing.

Group processing largely depends on managing these skills and competences. Even though technological facilitation enhances group processing possibilities through tracking and notifications, et al., motivation and encouragement process changes along with the new competence requirements for the group leaders. Dillendbourg et al. (1996) claims that research on collaborative learning variables proved difficulty in establishing links between conditions and effects of collaboration. Therefore, empirical research of this study was not based on the identification of the effects of online collaboration of students in university studies using Facebook as a social networking tool, but rather dealt with the researching of the conditions of this collaboration. Nevertheless, there is one important reason for student collaborative learning using Facebook in university studies, which is the use and exchange open educational resources. This was validated during the empirical research. However, this is interrelated with the effect of student collaboration, as well as new skills and competences that will be also analysed in the second part of this chapter. Even though it is very difficult to establish clear links between the conditions of collaboration and these effects, there is a need to introduce the concept of OER in terms of collaboration artefacts. 
DOI: 10.1515/arhss-2015-0006 Applied Research in Health and Social Sciences: Interface and Interaction, Vol. 12, No. 1,2015

\section{Open educational resources as the artefact of collaborative learning in university studies}

The term OER was first introduced at a conference hosted by UNESCO in 2002 and was promoted in the context of providing free access to educational resources on a global scale. OER are defined in this research as "teaching, learning and research resources that reside in the public domain or have been released under an intellectual property license that permits their free use or re-purposing by others. OER include full courses, course materials, modules, textbooks, streaming videos, tests, software, and any other tools, materials or techniques used to support access to knowledge (Atkins et al., 2007). To clarify further, OER is said to include these three areas:

- Learning content: Full courses, courseware, content modules, learning objects, collections and journals.

- Tools: Software to support the development, use, reuse and delivery of learning content, including searching and organisation of content, content and learning management systems, content development tools, and online learning communities.

- Implementation resources: Intellectual property licenses to promote the open publishing of materials, design principles of best practice and localise content.

The definition of OER is both broad and vague. A wide variety of objects and online materials can be classified as educational resources, from courses and course components to library or museum collections or open access journals and reference works. Over time the term has come to cover not only content, but also learning and content management software and content development tools, and standards and licensing tools for publishing digital resources. This allowed to users to adapt resources in accordance with their cultural, curricular and pedagogical requirements (OECD, 2007).

OER are made freely available over the web or the Internet. OER are used by teachers and educational institutions to support course development, but they can also be used directly by students in informal learning or at work placement by employees and business providers. OER include learning objects such as lecture material, references and readings, simulations, experiments and demonstrations, as well as syllabi, curricula and teachers' guides. Johnstone (2005) characterizes OER as:

- learning resources - courseware, content modules, learning objects, learner-support and assessment tools, and online learning communities;

- resources to support teachers - tools for teachers and support materials to enable them to create, adapt, and use open educational resources, as well as training materials for teachers and other teaching tools; 
DOI: 10.1515/arhss-2015-0006 Applied Research in Health and Social Sciences: Interface and Interaction, Vol. 12, No. 1, 2015

- resources to assure the quality of education and educational practices (OECD, 2007).

Toumi (2006) presents alternative views on OER as both individual and social development that include:

- freely accessible assets and services that support competence development and individual growth (learner's view),

- freely accessible assets and services that support teaching and professional development (teacher's view);

- non-rival and non-exclusive assets that generate services for learners and teachers (economic view);

- modifiable and interoperable systems for learning (technical view);

- free services for learning (institutional view).

Thus learning is not only about moving knowledge into the learners mind, but it is about developing capabilities to think and act. Learning can create knowledge that did not exist before.

When learners use social networking tools for collaborative learning, they act (respond, interact to support and express intimacy, immediacy and involvement (Biocca et al., 2006), they provide feedback and peer-review, and also assess and rate information (Redecker et al., 2009). The learner interaction and collaboration shows a clear link to developing capabilities to think and act. However, another question is if this artefact of collaboration can be treated as OER or not.

Many authors have discussed the OER concept and argue whether and when educational resources are "open". Several suggestions have been made as to how the term "open" should be interpreted in relation to OER. Walker defines 'open' as “convenient, effective, affordable, and sustainable and available to every learner and teacher worldwide" and D'Antoni speaks of "The 4 A's - accessible, appropriate, accredited, affordable" (Downes, 2006). Downes (2006) argues that "the concept of 'open' entails, it seems, at a minimum, no cost to the consumer or user of the resource" and goes on to say that "It is not clear that resources which require some sort of payment by the user - whether that payment be subscription fees, contribution in kind, or even something simple, such as user registration - ought to be called 'open'. Even when the cost is low - or 'affordable' - the payment represents some sort of opportunity cost on the part of the user, an exchange rather than sharing"(OECD, 2007). The 'open' may mean "without cost" but it does not mean "without conditions". The concept of "openness" is based on the idea that knowledge should be disseminated and shared freely on the internet for the benefit of society as a whole. Two of the most important aspects of openness have to do with free availability and as few restrictions as possible on the use of the resource, whether they be technical, legal or price barriers. Openness exists in different forms and domains and has different meanings in different contexts. Figure 2 
DOI: 10.1515/arhss-2015-0006 Applied Research in Health and Social Sciences: Interface and Interaction, Vol. 12, No. 1,2015

summarizes the different aspects of openness. Tuomi (2006) distinguishes three quite independent areas where openness makes a difference:

- in the social domain (the freedom to use, freedom to contribute, freedom to share);

- in the technical domain [functional (use of open standarts) and developmental (use of open source software)];

- as the characteristic of the resource (public goods and open fountain of goods).

One has to do with technical characteristics, the second with social characteristics, and the third with the nature of the resource itself. For example, the technical domain is characterised by access to source code and/or access to interoperability standards or the standards process. Openness in the social domain is fundamentally motivated by the expected social benefits and by ethical considerations related to the freedom to use, contribute and share. The more people use the service, the more valuable it is to have access to it. These so-called "open fountains of goods" form yet another kind of open resource. In this social domain, one may distinguish three different hierarchical levels of "openness".

"Openness I" is about access and accessibility. At this first level, one can access the resource. "Accessibility" can, however, also prelate to individual capabilities. For example, there may be course content freely available, but it is in a foreign language the user does not understand. Accessibility in the broad sense may be important, for example, for policymakers. A practical criterion for level I openness is whether there is a non-discriminatory opportunity to reach, explore, and study the resource.

"Openness II" is about the right and capability to enjoy the services generated by the resources. In educational settings, one can, for example, run a computer module. However in a broader sense, full use includes the possibility to access all the services generated. If the learner has access to the resources that is open at this second level, one gets full benefits out of its use.

"Openness III" is about the right and capability to modify, repackage, and add value to the resource; openness at level II is about free access to services generated by a resource, while at level III the user can use the resource itself. At this level, the traditional distinction between "consumer" and "producer" becomes blurred. In open source research and innovation studies, the term "user-producer" is frequently used to highlight this blurring of roles. Level III openness is, however, also important for teachers and content producers in the traditional model. Copyright regimes usually define "fair use" rights that provide limited openness at level III.

According to Tuomi (2006) a higher level of openness is about the right and ability to modify, repackage and add value to the resource. The conclusion can be made that collaborative learning using 
social networking tools creates artefacts which can be attributed to OER on openness level I and II. In some cases, the openness of level III can be reached, when conditions are based on technical possibilities, user skills and authorship/ copyright agreements.

Thus university students collaborate online and learn using mediated communication (Web 2.0 tools for social networking), use and exchange OER, as well as develop them as the artefacts of online collaborative learning. This concept scenario enlarges collaborative learning characteristics, as well. Students do not only implement collaborative learning which is based on a task. They influence task design by creating "education resources" themselves.

To avoid misinterpretation of the concept "educational resources" it should be stated that "educational resource" is understood here not only as learning resources actually used for teaching and learning, but the advantage is that the concept of "educational resource" avoids making an a priori stipulation that something is, or is not an educational resource. On the contrary, educational resources are resources enabling the development of both, individual and group capabilities for understanding and acting focusing on a given task or setting up a new collaborative unit to learn additional conditions and to bring collaborative artefact to the original setting to implement the task. It is well established that educational resources are also used for informal or non-formal learning, inside and outside formal educational settings.

Learners also learn by creatively using resources not intended for learning purposes. A similar view might be taken by teachers, namely that an educational resource is "anything that can be used to organize and support learners learning experiences".

OER are not often familiar to different sectors of education. Moreover, limited services that could facilitate and bring added value to OER use and re-use are also under the great need. Some initiatives have been established to solve the complex problem: lack of awareness, insecurities about legal aspects and quality, and lack of interoperability and easy - to - use repositories. As Kalz et al. (2010) indicate, the OpenScout project (http://www.openscout.net) aims at creating conditions for OER use and recontextualization. The authors agree that additional and added-value services that are under development will be related also with user competence models and user skills to provide feedback and rating of OER.

From the perspective of the learner, OER has great potential because an independent learner who has an affordable connection to the internet can access material from some of the best universities in the world. The teachers can produce or reuse the content as the students and within the institution teachers may be reluctant to use the materials from someone else. They can create excellent material and allow to others to use. Turning to the institution, one of the potential benefits of OER is seen to be a change in the way in 
DOI: 10.1515/arhss-2015-0006 Applied Research in Health and Social Sciences: Interface and Interaction, Vol. 12, No. 1, 2015

which education is provided. Because everyone can see everyone else's materials, the process can also promote internal cooperation in quality control.

It should be acknowledged that OER is not the only one type of artefacts that can be identified after successful collaborative learning facilitated by web 2.0 tools. Competences development is another very important artefact that should be further discussed and identified. Due to limitation of the scope of the chapter, we leave competence development recognition topic to be theoretically developed in other research findings, however, generic competence development has been included in the empirical research part of this chapter to illustrate the potential and the scope of additional benefits of social networking via Facebook in university studies.

\section{Facebook phenomenon in undergraduate university studies}

The case of the Facebook phenomenon at Vytautas Magnus University. Social media enabled mass of people, to get connected into online networks as online communities. Facebook as an online networking tool has spread with extreme popularity among the youth, as well as thematic communities of practices.

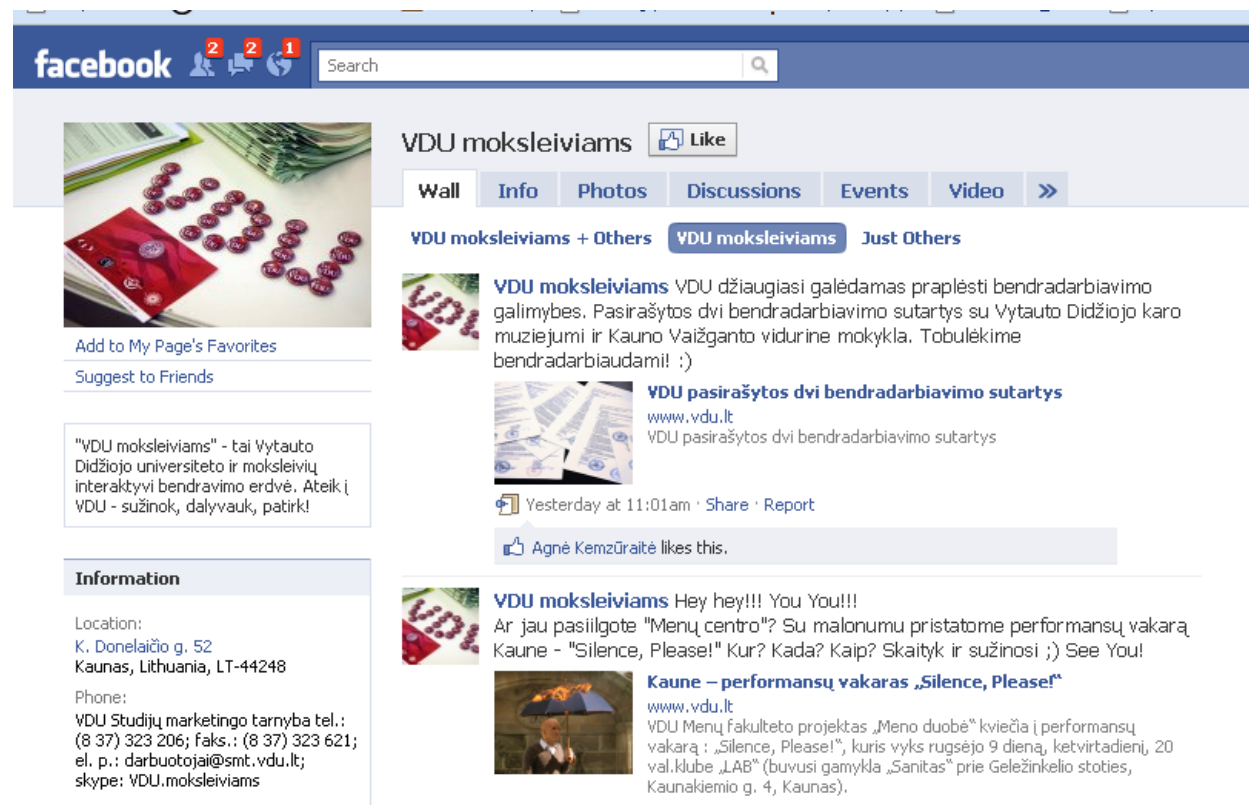

Figure 1. VMU Facebook group

Facebook online user communities can be addressed by researchers to identify their interest categories, literacy level, occupation and other dimensions. It is difficult to say whether 
DOI: 10.1515/arhss-2015-0006 Applied Research in Health and Social Sciences: Interface and Interaction, Vol. 12, No. 1, 2015

Facebook contributes to the efficiency of studies, as extensive survey is required to analyse arguments for or against; however, inevitable integration into Facebook online groups has been identified at different levels of at Vytautas Magnus University (VMU). A Facebook group has been created for the general VMU community social networking (Figure 1). A character called "Vytas" (which is a male Lithuanian name and a short version of "Vytautas") invites academic community members to various informal university events: academic year initiation day, performance evenings, basketball news, study guidance on study programs, art events, etc. The VMU Facebook group has been administered by Department of Public Communications. A total of 1555 users marked that they like this website. This group is open to the entire university community as well as to those who do not study or work at VMU. The second level of social networking is implemented within the level of study departments. The Department of Social Sciences has a Facebook group where events and other non-formal discussions and information sharing is moderated by the administrator at the department (Figure 2). 475 members marked that they like this page. This group is targeted at those studying and working at the Department of Social Sciences.

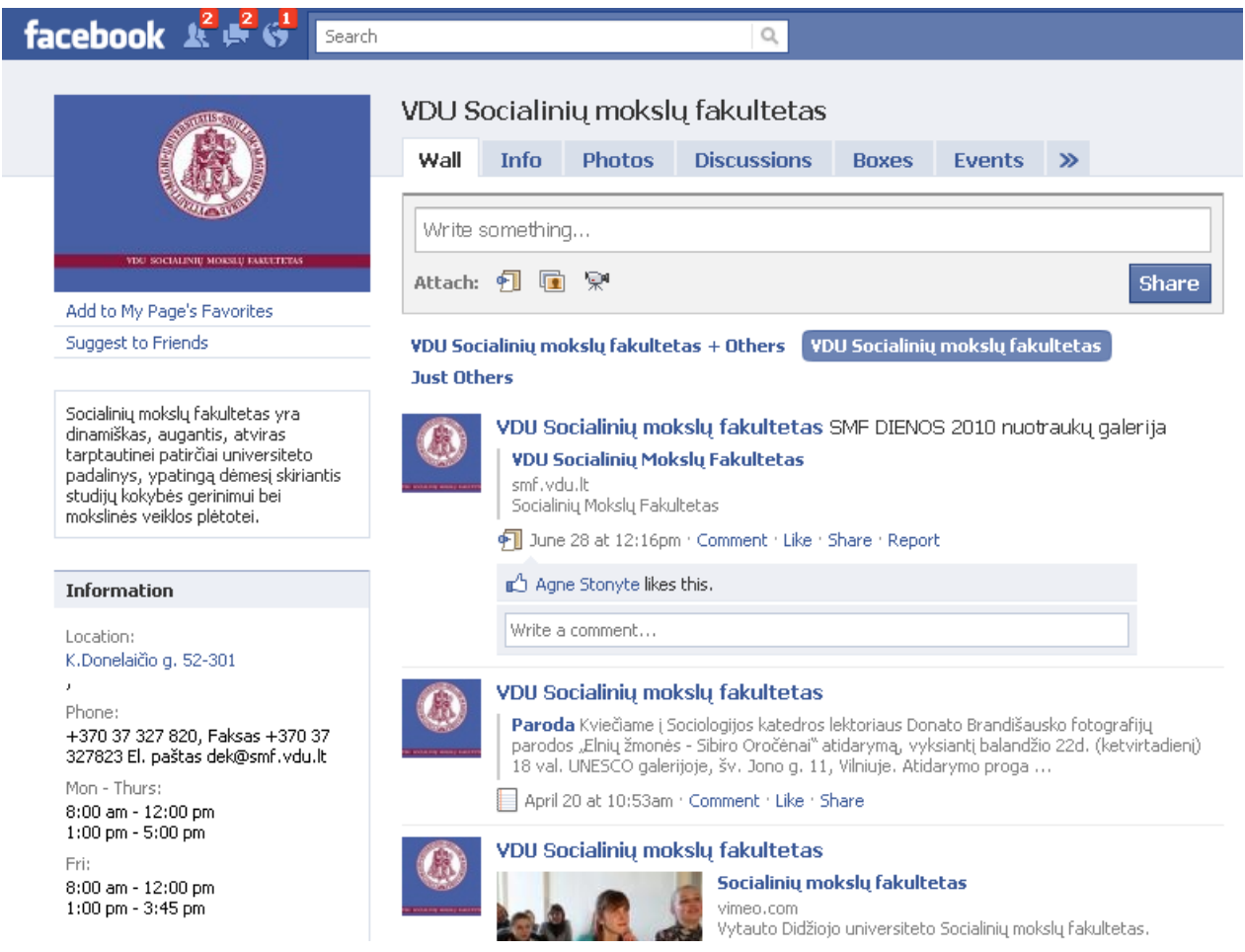

Figure 2. VMU, Department of Social Sciences Facebook group 
The main discussions within this group are related to faculty events, exhibitions, thematic workshops and debates, and information about Erasmus activities. The third level of communication on Facebook social network is a separate student course group within the Department of Education. Each course has its own Facebook group. Fourth year students (21 members) share knowledge and information related to studies and non-formal events. This group membership is open only to fourth-year Education Service Management students. In this group, the discussions and sharing of information is not public. However, students shared their experience described in the case below. The focus group method was used to interview 2 groups.

It must be mentioned that additional possibilities for students to use Facebook in international settings and groups were provided. A Facebook group was created for TeaCamp, which is a lifelong learning program under the auspices of the Erasmus Virtual Campus project that allows students of education to share information about studies at their respective universities (you can find out more about at TeaCamp at www.teacamp.eu). Students of education were invited to join the Facebook group in order to discover and explore new aspects of information collaborative learning. This possibility was not used very efficiently during the case research. However, after the publication was prepared and research results described, virtual mobility sessions were started. Then active participation and merging among various student groups was noticed in the TeaCamp Facebook group. It might be presumed that the informal education setting inspired students to visit and join the Facebook group. However, this hypothesis should still be validated in further research.

\section{Results}

Collaborative learning experience. Collaborative learning is based on the process of working together. It is a philosophy of interaction and personal lifestyle. During collaboration, students are also in charge of obtaining the additional learning resources. Research results showed that not all students understood the concept of collaboration correctly. Some students related collaboration only to group work. However, after they were asked to explain the concept, we found out that during group work they collaborated with each other and students from other groups. Most of the students understand the concept of collaborative learning as working in peers or groups. Students interviewed in the survey highlighted that they gained collaborative learning experience during workshops, lectures and distance learning courses. Some students also gained collaborative learning experience after self-studies (Table 1). 
DOI: 10.1515/arhss-2015-0006 Applied Research in Health and Social Sciences: Interface and Interaction, Vol. 12, No. 1, 2015

Table 1

\section{Collaborative learning experience}

\begin{tabular}{|c|c|c|}
\hline Category & Subcategory & Examples from the interviews \\
\hline \multirow{8}{*}{$\begin{array}{l}\text { Collaborative } \\
\text { learning } \\
\text { characteristics }\end{array}$} & $\begin{array}{l}\text { Collaboration at } \\
\text { workshops }\end{array}$ & $\begin{array}{l}\text { we often had workshops where we worked in groups; we } \\
\text { were also given group tasks. }\end{array}$ \\
\hline & Collaboration in lectures & $\begin{array}{l}\text { I think we gained collaboration experience both in } \\
\text { seminars and lectures, teachers gave us group tasks } \\
\text { during the lectures. }\end{array}$ \\
\hline & $\begin{array}{l}\text { Collaboration in distance } \\
\text { studies }\end{array}$ & $\begin{array}{l}\text { we used collaborative learning approach in distance } \\
\text { studies; I collaborate at the university through the } \\
\text { Moodle. }\end{array}$ \\
\hline & $\begin{array}{l}\text { Collaboration in } \\
\text { volunteering activities }\end{array}$ & I collaborate with people while volunteering at an NGO. \\
\hline & Collaboration at home & $\begin{array}{l}\text { we communicate and collaborate after classes; } \\
\text { I share information while talking with friends. We have } \\
\text { discussions, sometimes I argue the opinions that I believe } \\
\text { are inexact; we do the task at home, then have a meeting } \\
\text { in a café with individually completed work, you get to } \\
\text { know your course mates better, discuss the topic, listen to } \\
\text { their opinions, argue and do the task. }\end{array}$ \\
\hline & Collaboration at work & $\begin{array}{l}\text { we collaborate at work; such collaboration is unofficial; } \\
\text { although the work is official, this communication is } \\
\text { unofficial. }\end{array}$ \\
\hline & $\begin{array}{l}\text { Collaboration on the } \\
\text { Internet }\end{array}$ & $\begin{array}{l}\text { when we had group work, the main communication tools } \\
\text { were Skype messages, also Facebook, FirstClass } \\
\text { mailbox; we also collaborate on Facebook now, share } \\
\text { information on different topics related to our studies. }\end{array}$ \\
\hline & $\begin{array}{l}\text { Use of different learning } \\
\text { tools for collaboration }\end{array}$ & $\begin{array}{l}\text { telephone; Skype; Facebook, Twitter; Gmail, Yahoo or } \\
\text { other emails; FirstClass mailbox. }\end{array}$ \\
\hline
\end{tabular}

Students use different means for academic collaboration and collaboration in other environments, such as the workplace, volunteering engagement etc., but the most commonly used means are telephone, emails, Skype and social networks (Table 2). 
DOI: 10.1515/arhss-2015-0006 Applied Research in Health and Social Sciences: Interface and Interaction, Vol. 12, No. 1, 2015

Facebook social network benefits for collaborative learning. Students describe Facebook as a tool for communication and collaboration, as they are using it for sharing information with friends, finding new friends, setting up various groups, sharing information about themselves, non-formal discussions and sharing resources (Table 2). Students appreciate Facebook where various friend groups and organization groups are set up. Most of the students who participated in the research belong to two to five various groups in Facebook (including the VMU group, the Department of Social Sciences group, Department of Education group, VMU folk dance “Žilvitis” group, Dance studio "FU” group, Lithuanian Students Union group, Life summer festival group, University of Portugal group, and different secondary school groups) and have been using social networks between one to five years. Students indicated that they are also actively use other social networks such as Twitter. Some students communicate with their peers and friends in this network and also collaborate with various organizations to establish new contacts. Students also join this network for study purposes in order to find necessary information faster, to share experience in accomplishing different tasks, to get ready for exams or to get information for their final thesis or research from specific groups. Social networks are also noted for their openness, and Facebook is no exception. As Table 2 information shows, it provides not only a possibility to communicate with friends but also enables online community building with all registered users, to establish new contacts, view personal profiles, learn about various types of events, plan meetings with the help of a calendar and see how many people are planning to attend them (Table 2).

Table 2

Facebook's positive and negative aspects

\begin{tabular}{|c|c|c|}
\hline Category & Subcategory & Examples from interviews \\
\hline \multirow{3}{*}{$\begin{array}{l}\text { Facebook } \\
\text { social } \\
\text { network's } \\
\text { positive } \\
\text { aspects }\end{array}$} & $\begin{array}{l}\text { Stimulates participation of } \\
\text { users }\end{array}$ & $\begin{array}{l}\text { finding new acquaintances, establishing and maintaining } \\
\text { contacts; see what a person is doing in his/her life because } \\
\text { people upload their photos there, so you may know what } \\
\text { your friends are doing. }\end{array}$ \\
\hline & $\begin{array}{l}\text { Stimulates setting up groups } \\
\text { in social network }\end{array}$ & $\begin{array}{l}\text { there are all kinds of groups there, from chocolate lovers to } \\
\text { various education institutions were you can join or create by } \\
\text { you self the new one. }\end{array}$ \\
\hline & $\begin{array}{l}\text { Stimulates communication } \\
\text { and collaboration in social } \\
\text { network }\end{array}$ & $\begin{array}{l}\text { groups help me to find out about events for my leisure time, } \\
\text { it is important for me, because the date of the event is } \\
\text { announced in Facebook and you can inform about your } \\
\text { participation, or say that you will not participate or maybe } \\
\text { participate, see who else will go there. }\end{array}$ \\
\hline
\end{tabular}


DOI: 10.1515/arhss-2015-0006 Applied Research in Health and Social Sciences: Interface and Interaction, Vol. 12, No. 1,2015

Continuation of Table 2

\begin{tabular}{|c|c|c|}
\hline Category & Subcategory & Examples from interviews \\
\hline & $\begin{array}{l}\text { Stimulates teaching / } \\
\text { learning in social network }\end{array}$ & $\begin{array}{l}\text { I use Facebook mostly for study purposes; we share } \\
\text { information with friends whom we seldom see, but mostly } \\
\text { it's communication and information sharing; Facebook is } \\
\text { helpful for studies because we discuss many study-related } \\
\text { things; if you need a dictionary, for instance, you post on } \\
\text { your Wall and friends who may help answer at once; you } \\
\text { may also exchange any information; preparation for exams, } \\
\text { for instance; sharing information with far-away friends; I } \\
\text { spend about } 40 \text { percent of time for study related information } \\
\text { and60 percent for my personal life and friends. }\end{array}$ \\
\hline & $\begin{array}{l}\text { Stimulates openness in } \\
\text { social network }\end{array}$ & $\begin{array}{l}\text { I can browse the material or information from other groups; } \\
\text { Facebook is open to everybody. }\end{array}$ \\
\hline $\begin{array}{l}\text { Facebook } \\
\text { Social } \\
\text { network } \\
\text { negative } \\
\text { aspects }\end{array}$ & $\begin{array}{l}\text { Non-participation in social } \\
\text { network }\end{array}$ & $\begin{array}{l}\text { it is not such a necessary thing; I do not use Facebook, } \\
\text { because I don't know how to use the computer; Facebook is } \\
\text { really not part of my life, I only use it sometimes to meet my } \\
\text { peers; I connect very seldom and use Facebook very little; I } \\
\text { am not registered at all, I am not good with computers. }\end{array}$ \\
\hline
\end{tabular}

Some students have also found Facebook social network unnecessary because they do not use it and do not join any groups. The reasons of not participating in Facebook were not investigated in this survey; therefore we may only presume that the answer of this respondent is related with elementary computing skills. In the case of Education Service Management study programme students, their participation in Facebook social network has a positive effect on their university studies when students find benefits in sharing information on curriculum requirements, examination content, and performing tasks. They are interested in information disseminated in other groups and identify themselves as members of a certain group, e.g. VMU group, Faculty of Social Sciences group, Education Service Management study programme students group or other associations. Students also find permanent access to data important. Some networking tools used in university have time limits concerning its access whereas the time of being in Facebook is unlimited (Table 3). 
DOI: 10.1515/arhss-2015-0006 Applied Research in Health and Social Sciences: Interface and Interaction, Vol. 12, No. 1, 2015

Table 3

Benefits of Facebook for university studies

\begin{tabular}{|c|c|c|}
\hline Category & Subcategory & Examples from interviews \\
\hline \multicolumn{3}{|c|}{ Positive aspects } \\
\hline \multirow{2}{*}{$\begin{array}{l}\text { Benefits of } \\
\text { Facebook social } \\
\text { network for } \\
\text { university studies }\end{array}$} & $\begin{array}{l}\text { Identification through } \\
\text { Facebook social network } \\
\text { groups }\end{array}$ & $\begin{array}{l}\text { being a member of VDU group you identify yourself as a } \\
\text { university student; I identify myself for the friends that I of a } \\
\text { student from VMU. }\end{array}$ \\
\hline & Unlimited access time & $\begin{array}{l}\text { you may stay all day in Facebook, while other university } \\
\text { networking tools have limits and the session time ends, } \\
\text { repeated logging in is often unsuccessful and you waste your } \\
\text { time. }\end{array}$ \\
\hline & $\begin{array}{l}\text { Dissemination of } \\
\text { information }\end{array}$ & $\begin{array}{l}\text { the key aspect is dissemination of information because many } \\
\text { people use Facebook and regularly connect to it, more often } \\
\text { than FirstClass; sometimes we receive information about the } \\
\text { delivery of homework or a task and how to do it or when to } \\
\text { deliver it. So if go to Facebook I don't miss the deadline and } \\
\text { deliver my homework on time. Off course I naturally receive a } \\
\text { better mark, and get advice on how to do it better. }\end{array}$ \\
\hline & Discussions & $\begin{array}{l}\text { I read all discussions on Facebook; With the group we } \\
\text { discuss a lot about studies and coming assessments. }\end{array}$ \\
\hline \multicolumn{3}{|r|}{ Negative aspects } \\
\hline \multirow[t]{2}{*}{$\begin{array}{c}\text { Benefits of } \\
\text { Facebook for } \\
\text { university studies }\end{array}$} & $\begin{array}{l}\text { No file transferring } \\
\text { feature }\end{array}$ & $\begin{array}{l}\text { Facebook doesn't have a file sending feature, so I have to } \\
\text { leave the social network and use other applications to transfer } \\
\text { files. }\end{array}$ \\
\hline & $\begin{array}{l}\text { Too high involvement in } \\
\text { services offered by } \\
\text { Facebook }\end{array}$ & $\begin{array}{l}\text { some people are too involved in Facebook and spend too } \\
\text { much time in social networks; they cannot get away, and have } \\
\text { less time for doing homework and therefore their study results } \\
\text { are getting worse. }\end{array}$ \\
\hline
\end{tabular}

Negative aspects of Facebook indicated by the respondents are sending file and involvement in Facebook. According to the respondents you have to leave Facebook and to find another tool to send the files you want, because this social network doesn't have a tool for that.

The research participants indicated that some people are too involved in Facebook and spend too much time in social networks. Some of the students think that they cannot get away, and as a result they have less time for doing homework, thus the study results are worse. 
DOI: 10.1515/arhss-2015-0006 Applied Research in Health and Social Sciences: Interface and Interaction, Vol. 12, No. 1, 2015

Facebook social network learning approaches. Students show the need for more active and involving teaching and learning experiences and environments. In this case, social networks offer students more possibilities to communicate, learn, discuss, exchange information, reflect, judge and rate downloaded study materials, give feedback and acquire new knowledge on the Internet.

Table 4

Learning methods in Facebook

\begin{tabular}{|c|c|c|}
\hline Category & Subcategory & Examples from interviews \\
\hline \multicolumn{3}{|c|}{ Present aspects of learning approaches } \\
\hline \multirow[t]{4}{*}{$\begin{array}{l}\text { Features of } \\
\text { learning } \\
\text { approaches }\end{array}$} & $\begin{array}{l}\text { Information receiving } \\
\text { / information delivery }\end{array}$ & $\begin{array}{l}\text { Sharing information with friends who are far away; if you need a } \\
\text { dictionary, for instance, you post [a question] on your Wall and } \\
\text { friends who may help answer at once; you may also exchange any } \\
\text { information. }\end{array}$ \\
\hline & $\begin{array}{l}\text { Meta-reflexion / } \\
\text { asking questions }\end{array}$ & $\begin{array}{l}\text { Certain information is posted, than we start talking about that } \\
\text { information, clarify things, ask questions and give comments; } \\
\text {.during four years of studies I have done different tasks in groups, } \\
\text { we made group homework discussing it on Facebook; we ask for } \\
\text { advice on how to do the task; Facebook has a Wall and information } \\
\text { is posted on that Wall, then everybody can comment on it, so we } \\
\text { comment. }\end{array}$ \\
\hline & $\begin{array}{l}\text { Debating the } \\
\text { moderation }\end{array}$ & $\begin{array}{l}\text { (...we discuss..., ...we set up forums for a certain topic or have a } \\
\text { general discussion..., ....sometimes there are debates too..., ... we can } \\
\text { debate, we always discuss the dates of defending our theses in the } \\
\text { Department, about defending bachelor theses..., ...we talk about } \\
\text { exams, theses defence, share topics...). }\end{array}$ \\
\hline & $\begin{array}{l}\text { Exploration / } \\
\text { resource analysis and } \\
\text { recommending }\end{array}$ & $\begin{array}{l}\text {...we give comments..., ...now we are getting ready for the } \\
\text { Education Quality Assurance exam and had an in-depth discussion } \\
\text { about the form and content of this exam because we received the } \\
\text { task and have to decide how we will deliver it; after our discussion } \\
\text { on Facebook we will present our proposals to the teacher..., } \\
\text {...sharing information with far-away friends... }\end{array}$ \\
\hline
\end{tabular}

Not all web-based media motivate students to act; however in the case of social networking, students gave preference to Facebook to achieve better learning results. In addition to study related activities, they could share their personal information; communicate with other groups of their preference about studies, 
DOI: 10.1515/arhss-2015-0006 Applied Research in Health and Social Sciences: Interface and Interaction, Vol. 12, No. 1,2015

work, leisure time. The survey results have revealed that students use the majority of learning methods in the Facebook environment (Table 4).

It turned out that in Facebook, students used most of the learning patterns distinguished by Leclercq and Poumay (2005). In this social network, students delivered and received information, explored and analysed resources, recommended them to other course mates, debated frequently, asked questions, addressed for help to prepare for lectures, planned and controlled their learning process.

The research participants did not mention such learning and teaching events as imitation/modelling, creation/conformation, and exercising/guidance, as they were not identified by students in Facebook.

Development of generic competencies through Facebook. The development of generic competencies through collaboration is an inseparable part of the study process, therefore the development of generic competencies by the Facebook environment is important for learning process. The use of social networks can help students to overcome a certain reluctance to use meta reflection concerning their learning experience.

Discussing studies can increase a student's level of motivation or study quality. The research findings showed that the respondents developed competencies through Facebook. According to the interview results, it seems that it is important to them and for their learning process, as well.

During learning in Facebook students successfully collaborated, gained learning experience and developed general skills like information management skills, elementary computing skills, planning and time management, oral and written communication in one's native language, capacity for analyses and synthesis, problem solving and capacity to learn etc.

Competencies that ranked lower were the ability to work autonomously, basic general knowledge in the field of study, capacity to adapt to new situations, capacity to communicate in foreign languages, teamwork skills, knowledge of a second language, ability to generate new ideas, critical and self-critical abilities, and ability to work as part of an interdisciplinary team (Table 5). 
DOI: 10.1515/arhss-2015-0006 Applied Research in Health and Social Sciences: Interface and Interaction, Vol. 12, No. 1,2015

Table 5

Generic competencies development through Facebook

\begin{tabular}{|c|c|c|}
\hline Development of generic competencies & $\begin{array}{c}\text { Strongly } \\
\text { agree } \\
\text { (students) }\end{array}$ & $\begin{array}{c}\text { Agree } \\
\text { (students) }\end{array}$ \\
\hline $\begin{array}{l}\text { Information management skills (ability to retrieve and analyse information from } \\
\text { different sources) }\end{array}$ & 19 & 1 \\
\hline Elementary computing skills & 19 & 1 \\
\hline Planning and time management & 15 & 3 \\
\hline Oral and written communication in your native language & 13 & 6 \\
\hline Capacity for analyses and synthesis & 11 & 9 \\
\hline Problem solving & 11 & 7 \\
\hline Capacity to learn & 10 & 9 \\
\hline Ability to work autonomously & 8 & 12 \\
\hline Basic general knowledge in the field of study & 8 & 10 \\
\hline Capacity to adapt to new situations & 8 & 9 \\
\hline Capacity to communicate in the foreign languages & 7 & 10 \\
\hline Teamwork skills & 6 & 14 \\
\hline Knowledge of a second language & 6 & 9 \\
\hline Ability to generate new ideas & 4 & 10 \\
\hline Critical and self-critical abilities & 3 & 9 \\
\hline Ability to work in an interdisciplinary team & 3 & 8 \\
\hline
\end{tabular}

Analysis of the interview transcripts showed that students collaborate with each other in the different social networks, and that Facebook as the social networking tool is the most popular in Lithuania. Many students agree that using the social network helps them to develop generic competencies and to know each other as a group throughout discussion forums, sharing open educational resources, comments on the walls and group works. Facebook enables also collaboration, which helps respondents to find resources they are searching for and improve the atmosphere of the group. According to respondents, this social network also can be used for searching and storage of OER. The research also showed that Facebook stimulates communication and collaboration in social network, and learning in social network, openness in social network and provides dissemination of information, discussions, information receiving, metareflexion, debating, exploration, resource analysis and recommending sources. 
DOI: 10.1515/arhss-2015-0006 Applied Research in Health and Social Sciences: Interface and Interaction, Vol. 12, No. 1,2015

\section{Conclusion}

Collaborative learning is an educational approach to teaching and learning that involves groups of learners working together to solve a problem, complete a task, and create a product and to work toward a common goal. Also collaborative learning is asynchronous online learning among learning communities. Conditions for collaborative learning are based on group composition, task features and communication media. Online learning is based on Web 2.0 tools expanding the group composition drastically in terms of geographical, cultural and national scope, and might depend upon communication media used, as online communities might be built using different web 2.0 tools and might belong to different online community sets, but also might be interlinked and mingled by technological solutions.

Learning is about developing capabilities to think and to act. Learners using social networking tools for collaborative learning, act, provide feedback and peer-review, asses and rate information. Openness is based on the idea that knowledge is disseminated and shared freely for the benefit of society as a whole. University students collaborate online and learn by using and exchanging OER, as well as developing them as the artefacts of online collaborative learning. They influence task design by creating "educational resources" themselves. Inevitable integration of Facebook social network online groups has been identified at three different levels at Vytautas Magnus University. A first level Facebook group has been created for general VMU academic community social networking. This group is open to the entire university community as well as to those who do not study or work at VMU. A second level Facebook group has been created for the Department of Social Sciences. This group is targeted at those studying and working at the Department of Social Sciences. The third level of communication on Facebook is a separate student course group within the Department of Education. This group membership is open only to fourth-year Education Service Management students, and it was the focus group of this empirical research. Facebook stimulates communication and collaboration in a social network environment, teaching and learning, openness, and provides for dissemination of information, discussions, receiving of information and information delivery. It also facilitates meta-reflexion and the asking of questions, debating and debate moderation, exploration and resource analysis. It also enables students to collaborate within a group and to communicate with other groups on the basis of their interests.

\section{References}

Arends, R., (1998). Mokomés mokytis. Vilnius: Margi raštai. 
DOI: 10.1515/arhss-2015-0006 Applied Research in Health and Social Sciences: Interface and Interaction, Vol. 12, No. 1, 2015

Akins, D. E., Brown, J. S., \& Hammond, A. L. (2007). A Review of the Open Educational Resources (OER) Movement: Achievements, Challenges and New Opportunities. Available at http://tinyurl.com/2swqsg (Retrieved on 22/06/2015).

Bennet, B., Rolheser-Bennet, C., \& Stevahn, L. (2000). Mokymasis bendradarbiaujant. Vilnius: Margi raštai.

Biocca, F., Burgoon, J., Harms, Ch., \& Stoner, M. (2006). Criteria and scope conditions for a theory and measure of social presence. Media interface and network design Labs. Available at http://en.scientificcommons.org/frank_biocca (Retrieved on 22/06/2015).

Dillendbourg, P., Baker, M., Blaye, A., O'Malley, C. (1996) The evolution of research on collaborative learning. In E. Spada \& P. Reiman (Eds.). Learning in Humans and Machine: Towards an interdisciplinary learning science. (pp. 189- 211). Oxford: Elsevier.

Downes, S. (2006). Models for Sustainable Open Educational Resources. National Research Council Canada. Available at www.oecd.org/document/32/0,2340,en_2649_33723_36224352_1_1_1_1,00.html (Retrieved on 22/06/2015).

Tuning Educational Structures in Europe (2003). Final Report, Phase One Ed. Julia Gonzalez; Robert Wagenaar. University of Deusto. University of Groningen.

Fullan, M. (1993). Change Forces. London: Falmer Press.

Galbraith, M. (1995). Community-based organization and the delivery of lifelong learning opportunities. Washington, DC: SPONS AGENCY National Inst, on Postsecondary Education, Libraries, and Lifelong Learning (ED/OERI),

OECD (2007). Giving Knowledge for Free: the Emergence of Open Educational Resources. Available at http://www.oecd.org/dataoecd/35/7/38654317.pdf (Retrieved on 22/06/2015).

Hiltz, S. R. (1998). Collaborative learning is asynchronous learning networks: Building learning. Available at http://www.aln.org/alnweb/journal/issue2/hiltz.htm (Retrieved on 22/06/2015).

Holland, D., Skinner, D., Lachicotte Jr., \& Cain, C. (1998). Identity and agency in cultural worlds. Cambridge: Harvard University Press.

Johnson, D., Johnson, R., \& Smith, K. (1991). Cooperative Learning : Increasing College Faculty Instructional Productivity. ASHE-ERIC Higher Education Report 4, Washington, D. C.: George Washington University.

Johnson, D. W., \& Johnson, F. P. (1987). Joining together: Group theory and group skills (3rd edition). Englewood Cliffs, NJ: Prentice-Hall.

Johnson, D. W., \& Johnson, R. T. (1987). Research Shows the benefits of adult cooperation. Educational Leadership, 45(3), 27-30.

Johnstone, S. (2005). Open educational resources serve the World. Educause Quarterly, 28(3), 15-18.

Kagan, S. (1988). Cooperative learning: Resources for Teachers. Riverside, CA: University of California.

Kalz, M., Specht, M., Nadolski, R., Bastiaens, Y., Leirs, N., \& Pawlowski, J. (2010). OpenScout: Competence based management education with community-improved open educational resources. In: Halley et al. (Eds.). 


\section{DE DE GRUYTER \\ OPEN}

DOI: 10.1515/arhss-2015-0006 Applied Research in Health and Social Sciences: Interface and Interaction, Vol. 12, No. 1, 2015

Proceedings of the 17th EDINEB Conference. Crossing Borders in Education and work-based learning (pp. 137- 146). Maastricht: FEBA ERD Press.

Leclercq, D., Poumay, M. (2005). The 8 Learning Events Model and its principles. Available at http://www.labset.net/media/prod/8LEM.pdf (Retrieved on 22/06/2015).

Ocker, R. J., \& Yaverbaum G. (1999). Asynchronous computer-mediated communication versus face to face collaboration: Results on student learning, quality and satisfaction. Group Decision and Negotiation, 8, 427440.

Panitz, T. (1997). The Case for Student Centred Instruction Via Collaborative Learning Paradigms. Available at http://home.capecod.net/ tpanitz/tedsarticles/coopbenefits.htm (Retrieved on 22/06/2015).

Redecker, Ch., Ala-Mutka K., Bacigalupo, M., Ferrari, A., \& Punie, Y. (2009). Learning 2.0: The Impact of Web 2.0 Innovations on Education and Training in Europe. Final Report. JRS Scientific and Technical Report.

Slavin, R. E. (1991). Are cooperative learning and untracking harmful to the gifted? Response to Allan. Educational Leadership, 48(6), 68-71.

Smith, B. L., \& MacGregor J.T. (1992). Collaborative Learning: A Sourcebook for Higher Education. Washington, DC: National Center on Postsecondary Teaching, Learning, and Assessment, University Park, PA. 